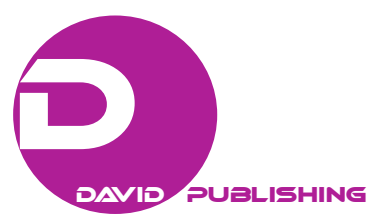

\title{
The Power of Money in FS. Fitzgerald's The Great Gatsby
}

\author{
Hasnul Insani Djohar \\ University of Exeter, Exeter, The United Kingdom \\ Syarif Hidayatullah State Islamic University, Jakarta, Indonesia
}

\begin{abstract}
The topic of this paper is the pursuit of cultural studies focusing on cultural hegemony, introduces the notion of the dominant groups' power to control society. It will also raise the issue of how hegemonic classes live in 1920s. The objective is to analyze, using cultural studies, Antonio Gramsci’s Hegemony, Scott Fitzgerald's The Great Gatsby in order to come to some conclusions about depictions of aristocratic classes and powers in order to dominate powerless groups. Specifically, the research focuses on Jay Gatsby's struggles to face the hegemony of aristocratic groups, whose affluent supremacy. In the story, the new moneyed group, represented by Jay Gatsby, lives in West Egg while the aristocratic group, represented by Tom Buchanan, lives in East Egg. Tom is always the winner because he comes from the aristocratic groups, whose prestigious family. Therefore, Gatsby always loses compete against Tom no matter how hard Gatsby tries. By learning Gatsby's struggle in this novel, we gain a better understanding of how other powerless groups, not only in American society, but also other society in the world, who also struggle to compete with the aristocratic groups.
\end{abstract}

Keywords: F. Scott Fitzgerald, The Great Gatsby, Hegemony, class, aristocratic group

Antonio Gramsci's idea of hegemony in Cultural Hegemony, introduces the notion of the dominant groups' power to control society. Gramsci defines hegemony as "manufactured consent created through the articulation of intellectuals in a public sphere in which contending articulations are also voiced" (Gramsci, 2010, p. 1000). It can also be read to claim that the power groups, the haves, dominate the have-nots. After the Great War, America went through great transformations politically, economically, socially, and culturally in the global world. Industrialism and business were very successful after the Great War, especially in the 1920s. These great revolutions also impacted the changes of the American society at the time. They divided American society into two mainstream hegemonic groups, the moneyed groups and the aristocratic groups. These influential groups had dominion over people. The power of the two majority groups can be seen in the remarkable American classic novel of F. Scott Fitzgerald's The Great Gatsby. In the story, the moneyed group, represented by Jay Gatsby, live in West Egg while the aristocratic groups, represented by Tom Buchanan, live in East Egg. Tom is always the winner because he comes from the aristocratic groups, whose prestigious and class family. Therefore, Gatsby always loses compete against Tom no matter how hard Gatsby tries.

This paper investigates the ways in which an American lost generation writer like F. Scott Fitzgerald thematizes the two hegemonic groups, the moneyed and aristocratic groups, achieve and maintain their

Hasnul Insani Djohar is a PhD candidate in American Literature at the University of Exeter and an awardee of Indonesian Endowment (LPDP) Funded PhD in English. She is a lecturer at Syarif Hidayatullah State Islamic University (UIN Jakarta), Jakarta, Indonesia. Her research focuses on culture (ethnicity), memory, and identity in contemporary American-Muslim women's writing. 
dominions in the 1920s. Fitzgerald's representative fiction not only educates readers in how to understand American society in the 1920s, but also how to appreciate American history after the Great War. Working primarily within a cultural study, using Antonio Gramsci's Hegemony, and an approach informed by Karl Marx's Capitalist theory, this essay investigates a range of authorial strategies for representing the haves experiences and considers how this novel bears witness to the influential groups in the 1920s.

When The Great Gatsby was first published, some critics argued that Fitzgerald's work was not really significant because it was written by a young poet. Frederick J. Hoffman argues in The Twenties, that Fitzgerald's work is

a revealing story of the very young in the decade. He [Fitzgerald] is, in his life and his tastes, an inseparable part of that story, a victim of the decade's own standards of judging people. He never quite makes the proper intellectual use of the disaster implicit in the behavior of the very young. (Hoffman, 1955, p. 118)

Hoffman believes that Jay Gatsby is a symbol of Fitzgerald's opportunity to defend his own young mistakes, but this judgment was insufficient, since Fitzgerald was too young to judge. This critique shows that how the aristocratic American society, represented by Hoffman, valued a lesson and an ideology based on whose doctrine it was instead of what the doctrine was. Simply because Fitzgerald was very young, then they believe that it is a tendency of young people to judge people without fully understanding the situations. The way Hofmann claims that Fitzgerald or young generations' perspectives as unimportant and insignificant can be said that it is the symbol or the legacy of the autocracy society, which often to judge people's capabilities based on their ages. This paper challenges Hoffman arguing that Fitzgerald's work represents the success of the young American poet to critique the aristocratic American society in the 1920s.

Relevantly, Robert Beuka's analysis of The Great Gatsby also challenges the scholars who critique the novelas a failure the first time it was published. For example, Mencken complained that the novel is "obviously unimportant" and "basic triviality" (p. 212). Mencken believed that Gatsby is only a "glorified anecdote" (p. 211). In order to challenge these critical perspectives, Beuka provides some criticisms that discuss the "changing interests, values, and methodologies in American literary criticism" (Beuka, 2011, p. 1). Beuka believes that the Gatsby has the everlasting cultural relevance of a novel that "was criticized for being too tied to its own historical moment to have any real shot at lasting appeal" (Beuka, 2011, p. 1). Beuka argues that the importance of the novel is the historicity of the text "from pervasive notions about race, gender, and national identity discussed in the popular magazines to the imagery offered in popular music and entertainment" (p. 119). Beuka's ideas about the historical importance of the novel can also be used to analyze how the aristocratic groups contribute to the issues of race, gender, national identity, and popular music in the American society in the 1920s.

In accordance with Beuka, Fitzgerald's The Great Gatsby can be seen as representative of how the aristocratic groups maintain their hegemonic power in every aspect of American society in the 1920s economically, politically, psychologically, and culturally. The have groups achieve their dominion through industrialism and business, which behaved as the consumer culture, and through the way they maintain their persona and images. They imitated advertisements, consumed materialism and pursued the luxury and leisure time. The great success of the hegemonic groups in the 1920s can also be seen in The Great Gatsby. The have groups achieve their hegemonic wealth through gambling and becoming racketeers. For example, the Jay Gatsby's model of gambler is Meyer Wolfsheim who inspired Gatsby to be a successful racketeer. 
Although Jay Gatsby succeeds economically, Tom Buchanan do not see Gatsby as a successful man because Tom believes that Gatsby is "Mr. Nobody from nowhere" (p. 138). Tom's statement demonstrates how the aristocratic groups have more power than the have groups because Tom sees Gatsby as an unimportant person. For Tom, Gatsby is not success because Gatsby gains his wealth through "dirty" business. In contrast, Tom seizes his wealth through "clean" business", just because Tom comes from a class family. In this novel, the aristocratic groups expands their hegemonic power by claiming that the have groups have dirty business and consider them as unimportant people.

Gatsby's obsessions for the products of a growing industrial society are an accurate depiction of cultural history of the 1920s. According to Lynn Dumenil, "in characterizing the 1920s as modern, I recognize that the essential transformations began in the late nineteenth century, with the triad of rapid industrialization, sprawling urbanization, and massive immigration" (Dumenil, 1995, p. 4). The rapid industrialization was clearly characterized by Henry Ford, the famous American auto manufacturer, who received the title of "The Ford Miracle" because of his spectacular success in manufacturing and selling automobiles. Like other innovators, Ford's great success in the entire world contributed to making the United States the dominant world economic power. The great success of industrialism transformed the lives of Americans who enjoyed a higher standard of living. Ironically, this success was largely enjoyed only by white Americans. Oppositely, most African Americans and other minorities continue to live in poverty and inferiority.

As reflected in the disparity between the lives of the affluent white majority and the isolated minorities, the effects of industrialism had a wider reach than the creations of a business culture. According to Susan Currell, the 1920s era has been only "characterized as an era of apolitical individualism, an era of business culture, hedonism and political retreat" but instead, "the period can more accurately be seen as an era cultural renaissance created from the very ambivalence, the irresolvable tensions, over ideas about the past and the possibilities of the future" (Currell, 2009, p. 2). Currell believes that the 1920s era was not only an era of business and hedonism, but more so an era of American cultural revitalizations. Currell provides some American cultural issues in her American Culture in the 1920s as follows: cultural decline, machine culture, the science of culture, the culture of science, culture as therapy, culture and religion, culture and race, culture and the new negro, and women and culture. Currell concludes that culture with all its diversities was the circle where the remarkable revision took place. These noteworthy adjustments also appear in Fitzgerald's Gatsby in which he tells a story of not only the great Gatsby but also the great America.

Currell starts her cultural explanations on how American civilization has begun with the cultural decline and ended in its stupendous readjustments. Currell (2009) states that "the pre-war experimentalism in culture had relied on a booming optimism about the future and progress, but the war exposed the bankruptcy of such idealism" (p. 2). Currell believes that historically war made America face new problems both in moral and industrial spheres. The rise of business culture impacts the rise of materialism, consumer culture, moral decline, and eventually corruption. Moreover, these great successes of industrialism led American society at the time toward materialistic values and lack in personal moral values. Currell adds, "the boom in business was fuelled by progress in new technologies and methods of mass production, which caused further anxieties over human culture" (p. 5). In that era, the mass productions and materialism of the characters ignored the moral need of human culture. It suggests that the negative impact of the great industrialism at the time influenced the personal moral values of the people where they tend to live individually, selfishly, and materialistically.

Fitzgerald successfully represents the American society at the time where moral and industrial zone meet 
together. During the time in which American society's individualism led to moral declines, the machine culture increased dramatically. For example, Jay Gatsby lives individually, busy focusing on his appearances and becoming richer by becoming a bootlegger. Simultaneously, Gatsby also buys into a machine culture: fancy car, yacht, and hydroplane. In the same way, Nick lives lonely in his small house next to Gatsby's great house struggling to learn a new business in New York in order to achieve the great success of business at that era. Fitzgerald portrays his characters hectically self-absorbed, more interested in money and luxury, neglecting the essential things in their lives, moral values.

The great success of industrialism led American society to be a consumer culture. It is very apparent throughout The Great Gatsby that Fitzgerald discusses his characters' morals and attitudes which tend to reflect their hedonism and materialism. His characters are only interested in the social life, such as fancy parties, loud orchestra, sparkling advertisements, and economical life, such as new car and new business, but not in political life such as the Great War. It can be seen from the way Tom and Gatsby talk. They are busy discussing their new commodities, their polo and golf sports and hobbies, their high class of Oxford and Yale men, but they very rarely talk about their experience in the Great War, even though they are also veterans like Nick. Likely, Fitzgerald's cynicism is reflected in his characters, especially Tom and Gatsby, who are not proud to be veterans of the Great War. The sparkling of industrialism and business made Fitzgerald's characters, Tom and Gatsby seemingly forget about their great experiences in the Great War.

The booming of industrialism and business at the time also contributed in making the society of the twenties spend their time leisurely. According to Lynd in Middletown, society "has always delighted in talk... much of its leisure time is spends in talking or listening to talk" (Lynd, 1956, p. 226). Lynd explains that American society spent their leisure time gathering and talking about materialism or superficial subjects, instead of serious issues like politics. This superficial conversation is also common in Fitzgerald's story. For example, when Nick has tea at Daisy's house, Jordan is gossiping about Tom's mistress, Myrtle. When Nick visits Myrtle's apartment, Myrtle is hectic discussing fancy clothes with her sister, and the other guests are drinking. When Nick comes to Gatsby's house, they are having a delightful party. When Gatsby has his first reunion with his old love, Daisy, in Nick's house, Gatsby is busy showing off his great amenities, from house, library, to his fancy clothes that make Daisy cry, "they are such beautiful shirts" (p. 92). When Nick joins the meeting in Plaza hotel, Daisy is admiring Gatsby saying that "you always look so cool" (p. 119). These examples provide how society in the twenties, represented by the novel, spend their time luxuriously and leisurely.

The way the twenties decade society spent their leisure time was mostly together with their spouses or their friends, never by themselves. Lynd opines that "the characteristic leisure-time pursuits of the city tend to be things done with others rather than by individuals alone" (p. 226). Lynd explains that the typical American society in the 1920s pursued their leisure time organized collectively and not personally. However, these characteristics are not applicable for Gatsby since in the story Nick mostly describes his time alone at home, and he does not describe having close friends with whom to spend his leisure time. Although Fitzgerald describes how Jay Gatsby spends his time with Daisy and her family, most of his time is alone. For example, he never joins the great parties that he organizes at his house; instead, he just watches them from his window. This novel can be seen as the irony of American society at a time when the great success of industrialism and business cannot guarantee the happiness of people. Although Jay Gatsby has all the great things, he is not 
happy since he lives alone, without his great love, Daisy.

The industrial era impacted personal values of the American society in the 1920s focusing on self-images such as clothes, cars, houses, and other superficial amenities. Lynd discusses the importance of clothing in Middletown. He believes that "clothing is forced to compete with automobiles, home ownership, children, and college educations" (p. 160). Lynd suggests that the functions of clothes have changed from covering one's body as a physical necessity to gaining social recognitions. The way Middletown views clothes is relevant to the way Gatsby values his colorful huge shirts and ties to highlight his self-images. This implies that the 1920's society lives focused on superficial matters like self-images rather than the essential ones like moral character.

American society at the time not only used their clothing to highlight their self-images, but also used business to strengthen their persona. According to Garet Garrett, "modern business derives from three passions in this order, namely: the passion for things, the passion for personal grandeur and the passion for power" (Garrett, 1971, p. 397). Garrett argues that business in the 1920s became a device to achieve great power and kingship, where humans had passions for conquest, practiced revenge, and dominated over people. This notion also relates to Gatsby's life when he has passions for achieving his power, practicing his revenge towards Tom to win his love back by showing off his great success, and feeling superior over people both in East and West Egg. This suggests that business at the time, also represented by Jay Gatsby, was aimed more to obtaining a power and persona than simply earning a living.

Critics have viewed American society in the twenties as a consumer culture. William Brevda explains how the advertisements and media contributed to this consumer culture that influenced American society in 1920s. According to Brevda (2011), "the great Gatsby portrays the new age of advertising. People check out signs, fashion themselves out of fashionable images, and market themselves as that magical image, becoming signs themselves" (p. 47). Brevda believes that American society lived surrounded by the sparkling of advertisements, and society tried to imitate the advertisement figures. The flourishing of the advertisement at the time led American society to become a consumer culture.

Furthermore, Fitzgerald depicts the aristocratic groups increase their power by exposing their prosperous wealth toward society. For example, when Tom has a wedding in the Seelbach Hotel, he provides Daisy a luxurious jewelry. Fitzgerald writes, "the day before the wedding he gave her [Daisy] a string of pearls valued at three hundred and fifty thousand dollars" (p. 76). This line shows how the power of money, which the affluent groups have, can buy anything, included respects and loves. Especially at the time, America experienced a cultural and lifestyle revolution. The have groups often to spend their time on parties and expensive properties, like automobile and jewelry. That's why Daisy cannot wait for Gatsby for a long time. The way Tom buys Daisy with a fancy necklace makes Gatsby loss of his love.

Gatsby tries to take his Daisy back. In order to compete with Tom, Fitzgerald depicts Gatsby struggles to increase his persona. He builds a great house, buys a fancy car, imports pretty clothes from England, and has an aero plane. However, Tom tries to find several ways to lose Gatsby. For example, Tom conducts an investigation saying, "I've made a small investigation of this fellow" (p. 122). Tom continues and asks Gatsby, "Who are you, anyhow?" "I found out what your drug store were"... "He and this Wolfsheim bought up a lot of side-street drug-stores here and in Chicago and sold grain alcohol over the counter. That's one of his little stunts. I picked him for a bootlegger the first time I saw him, and I wasn't far wrong” (p. 133). This line shows how Tom uses his influence to discredit Gatsby claiming that Gatsby is his "bootlegger". In fact, Tom also uses 
the dirty business because he hires Gatsby for the first time. However, since Tom comes from a prestigious family, no one can discredit him like Tom did to Gatsby. Gatsby loses his respected status in a society. After Daisy is convinced by Tom saying that Gatsby has a "dirty" business, she come back to her husband, and ignores Gatsby. Again, Gatsby loses his love, Daisy, for the second time. This case shows that a position and social status are more powerful than money. Although Gatsby has all money and persona, he remained lost and failed to compete against Tom, who has an aristocratic power.

Fitzgerald continues illustrating his antagonist, Tom, represent the aristocratic groups expanding their power in American society in the 1920s. For example, Fitzgerald depicts Tom who manipulates George Wilson and the police saying, "that yellow car I was driving this afternoon wasn't mine - do you here? (p. 140). Tom explains that the car, which kills George's wife, Myrtle Wilson, belongs to Gatsby. Although Tom knows that Daisy drives the car and hits Myrtle, Tom does not tell George and the police so. In fact, Tom positively convinces George that Gatsby killed his wife. Tom's supremacy as the aristocratic group contributes to make society believes in whatever he says and however he does. Tom's sovereignty can be seen through the way George comes directly to Gatsby's house, without checking and rechecking first, but pulls his gun toward Gatsby.

\section{Conclusion}

Fitzgerald's The Great Gatsby successfully portrays the struggles of the moneyed group, represented by Jay Gatsby, to compete against the aristocratic groups, represented by Tom Buchanan. Tom is always the winner because he comes from the aristocratic groups, whose prestigious and class family. Therefore, Gatsby always loses compete against Tom no matter how hard Gatsby tries. Importantly, through this novel, we learn how the hegemonic groups live in the 1920 . The hegemonic groups live glamorously and hedonically because industrialism and business were flourishing at the time.

By learning hegemonic classes and supremaciesin this novel, we can learn a better understanding that the aristocratic groups have more power than the have groups. By learning Gatsby's struggle in this novel, we glean a better understanding of how other powerless groups, not only in American society, but also other society in the world, who also struggle to compete with the aristocratic groups. Fitzgerald's the Great Gatsby has successfully critiques the way the aristocratic groups control and manipulate the powerless groups, including the moneyed-groups. That's why the importance of Gramsci's theory of hegemony in order to remind us all about the humanities and equalities, regardless legacies and declivities.

\section{References}

Balkun, M. M. (2006). The American counterfeit: Authenticity and identity in American literature and culture. Alabama: The University of Alabama.

Beuka, R. (2011). American icon: Fitzgerald's the Great Gatsby in critical and cultural context. New York: Camden House. Brauer, S. (2009). What makes him great? Teaching the Great Gatsby and the new historicism. Approaches to Teaching the Great Gatsby (pp. 84-94).

Brevda, W. (2011). Signs of the signs: The literary lights of incandescence and neon. Maryland: Bucknell University Press,.

Clymer, J. A. (1996). Mr. Nobody from nowhere: Rudolph Valentino, Jay Gatsby, and the end of American race. Genre, 29(1), 161-193.

Cowley, M. (1951). Exile's return: A literary Odyssey of the 1920s. New York: Viking Press.

Currell, S. (2009). American culture in the 1920s. Edinburgh: Edinburgh University Press.

Dettmar, K. (2008). F. Scott Fitzgerald: The Great Gatsby. In A Companion to Modernist Literature and Culture (pp. 342-350). 
Dumenil, L. (1995). The modern temper: American culture and society in the 1920s. New York: Hill and Wang.

Farr, C. K. (2009). Doubting Nick: Reading Nick Reading Gatsby Reading Daisy. In Approaches to Teaching Fitzgerald's The Great Gatsby (pp. 175-180).

Fitter, C. (1998). From the dream to the Womb: Visionary impulse and political ambivalence in The Great Gatsby. Journal $x$ Autumn, 3(1), 1-21.

Fitzgerald, F. S. (2004). The Great Gatsby. New York: Scribner.

Garrett, G. (1971). Civilization in the United States: An inquiry by thirty Americans. In Westport: Greenwood Press (pp. 397-416).

Gramsci, A. (2010). Cultural hegemony. In V. Leitch (Ed.), The Norton Anthology of Theory and Criticism. New York: W. W. Norton \& Company.

Hays, P. L. (2009). Enough guild to go around: Teaching Fitzgerald's lesson in morality. In Approaches to Teaching World Literature (pp. 169-178).

Hoffman, F. J. (1955). The twenties: American writing in the postwar decade. New York: The Viking Press.

Ickstadt, H. (1990). Transformations of the cultural idel: High culture, mass culture, and ideal images in the American novel from 1900 to the 1920s. Hungarian Studies in English, 21, 17-27.

James, P. (2009). Teaching Gatsby in the context of Great War I. In Approached to Teaching World Literature (pp. 32-41).

Lance, J. (2000). The Great Gatsby: Driving to destruction with the rich and careless at the Wheel. Studies in American Culture, 23(2), 25-26.

Lynd, R. S. (1956). Middletown: A study of American culture. New York: A Harvest Book.

Marx, K. (2010). Capital. In V. B. Leitch (Ed.), The Norton Anthology of Theory and Criticism (pp. 647-671). New York: W. W. Norton \& Compan.

Mathews, J. T. (2009). Money and things, capitalist realism, anxiety, and social critique in works by Hemingway, Wharton, and Fitzgerald. In A Companion to the Modern American Novel 1900-1950 (pp. 181-201).

McGowan, P. (2005). The American carnival of The Great Gatsby. Connotations, 15(1), 143-152.

Moreland, K. (2002). Music in The Great Gatsby and The Great Gatsby as music. In Literature and Musical Adaptation (pp. 29-45).

Moreland, K. (2009). Teaching Gatsby as American culture hero. In Approaches to Teaching World Literature (pp. 93-99).

Riggio, T. (2000). Dreiser, Fitzgerald, and the question on influence. In Theodore Dreiser and American Culture: New Readings (pp. 234-244).

Sickle, R. (2000). A countercultural Gatsby: Hunter S. Thompson's fear and loathing in Vegas, the death of the American dream and the rise of Las Vegas. Popular Culture Review, 11(1), 61-70.

Stearns, H. E. (1971). Civilization in the United States: An inquiry by thirty Americans. Westport: Greenwood Press.

Stoneley, P. (2008). The Great Gatsby as mobilization fiction: Rethinking modernist prose. In A Concise Companion to American Fiction, 1900-1950: Blackwell Concise Companions to Literature and Culture (pp. 132-57).

Taylor, D. (1971). Civilization in the United States: An inquiry by thirty Americans. In Westport: Greenwood Press (pp. 199-214).

Tunc, T. (2009). The Great Gatsby: The tragedy of the American dream on Long Island's Gold Cost. In The American Dream (pp. 67-80). 